\title{
Building Speaking Fluency with Multiword Expressions
}

Haidee Thomson

Previous research has shown a link between speaking fluently and using multiword expressions. However, evidence on how to effectively teach multiword expressions is limited. This study investigates the effect of fluency-oriented classroom teaching on speaking fluency, with special attention to multiword expressions. In this quasi-experimental study, a sequence of activities believed to foster fluency was implemented for 6 weeks in the classroom. The activity sequence was based on Wood's (2009) fluency workshop report. The students' gains in speaking fluency as well as their cued recall of multiword expressions were compared with a control group. Results show significant gains under the experimental condition for cued recall of multiword expressions $(N=73)$, but speaking fluency and the number of multiword expressions used in speech $(n=23)$ did not increase significantly when compared with the control group. The data also lend further support to the thesis that speaking fluency and use of multiword expressions are positively correlated. Learner feedback on the activities revealed "shadowing" to be one of the most favoured activities.

La recherche antérieure a démontré un lien entre le fait de parler une langue couramment et l'emploi d'expressions comportant plusieurs mots. Toutefois, la documentation sur l'enseignement efficace de telles expressions est limitée. Cette étude évalue l'effet de l'enseignement visant la maitrise de la langue sur la fluidité orale, notamment sur les expressions comportant plusieurs mots. Au cours de cette étude quasi-expérimentale, une séquence d'activités qui devraient promouvoir la fluidité a été mise en cuvre dans la classe pendant 6 semaines. Cette séquence d'activités reposait sur le rapport de Wood (2009) sur un atelier portant sur la fluidité. Les progrès en fluidité orale des étudiants et leurs résultats à une épreuve de rappel indicé portant sur des expressions comportant plusieurs mots ont été comparés à ceux d'un groupe témoin. Les résultats indiquent des progrès significatifs en rappel indicé dans les conditions expérimentales $(N=73)$. Par contre, l'amélioration de la fluidité orale et de l'emploi d'expressions comportant plusieurs mots $(N=23)$ n'était pas significative comparée à celle du groupe témoin. Les données appuient la thèse selon laquelle il existe une corrélation positive entre la fluidité orale et l'emploi d'expressions comportant plusieurs mots. Les commentaires des étudiants sur les activités révèlent que le "jumelage »était une des activités préférées.

KEYWORDS: multi-word expressions, L2 speaking fluency, formulaic language learning, classroom activities 
Learning to speak using a new language is fraught with risk of failure or negative evaluation (MacIntyre \& Gregersen, 2012). It is not surprising, then, that language learners often struggle to speak. In order to overcome lack of fluency in speaking, it has been suggested that fluency activities that make repeated use of familiar language under time pressure should be included in any balanced language learning program (Nation, 2014). Students, particularly in EFL situations, lack fluency practice opportunities as their language exposure and use is often limited to the classroom, and this may be further limited by a lack of fluency activities in the classroom. Canada has a large population who are learning English as a second or additional language, and even in this context, fluency activities need to be provided in the classroom (Derwing, Munro, \& Thomson, 2008; Rossiter, Derwing, Manimtim, \& Thomson, 2010). Additionally, fluency has been associated with knowledge and use of multiword expressions (see, e.g., Boers, Eyckmans, Kappel, Stengers, \& Demecheleer, 2006; Kuiper, 2004). Therefore this article will consider the efficacy of a set of classroom activities for building knowledge of multiword expressions and speaking fluency. First, research showing the association between multiword expression use and fluency will be introduced, followed by research on classroom language learning instruction and activities such as noticing, awareness raising, memorization, and repetition. The focus of this study, a sequence of classroom activities for building knowledge of target multiword expressions and speaking fluency called the fluency workshop (see Wood, 2009), will then be introduced. The efficacy of the fluency workshop will be investigated through a quasi-experimental study.

Language learners will often aspire to be fluent users of the language they are learning. Chambers (1997) states that "[f]luency is about effectiveness of language use within the constraints of limited linguistic knowledge" (p. 536). Segalowitz (2010) posits that fluency is multidimensional and can be divided into three broad senses: cognitive fluency (efficiency of planning and assembling utterances), utterance fluency (fluency characteristics such as pausing and speech rate), and perceived fluency (inferences of fluency that listeners make about the speaker). A speaker is under time pressure to construct an easy to comprehend message for the listener. If the message is generated word by word, pauses will be obvious. A speaker who manages to balance prefabricated constructions with novel constructions is likely to give the impression of a more fluent speaker (Chambers, 1997). In this article, language fluency narrowly refers to the speed and smoothness of delivery (Lennon, 1990).

Because of the limits to our processing capacity (inclusive of working memory), it is only natural that we attempt to streamline and shortcut what we can. This strategy of streamlining and shortcutting is assisted by our ability to organize and associate connections between our memories, "a basic associative learning process," otherwise known as chunking (Ellis, 2001, p. 40). People often streamline their thought processes through chunking related information or skills together (Dörnyei, 2009). In language, speaking fluently 
may be a result of similar chunking efficiencies. Chunking of words can be seen in the language use of toddlers, who use word clusters as functional communicative phrases before they actually understand the component words and structure, for example, what's that, look at that! (Peters, 1983). The importance of such chunking for adults is evidenced through the prevalence of multiword expressions in language corpora, where approximately $50 \%$ of all discourse consists of multiword expressions, according to Erman \& Warren (2000).

Multiword expressions (as defined by Siyanova-Chanturia \& Martinez, 2015) refer broadly to "(semi-)fixed recurrent phrases"; these are often frequent, familiar and formulaic word sequences such as I think I will and would you like to. Multiword expressions are not only prevalent throughout language, they have also been associated with fluency. Auctioneers and sports commentators who are known for their incredible speaking pace often use multiword expressions when speaking at speed (Kuiper, 2004), for example in horse race commentary ... is in the lead, ... is followed by ... (Kuiper, 1991, p. 27). Research has also shown that formulaic language takes less time to read, an indication that it is easier for people to understand word sequences that are familiar and easily anticipated (Ellis, Simpson-Vlach, \& Maynard, 2008; Siyanova-Chanturia, Conklin, \& van Heuven, 2011; Underwood, Schmitt, \& Galpin, 2004). The reduced processing load of multiword expressions can also make the details that surround the familiar multiword expressions easier to remember (see Tremblay, Derwing, Libben, \& Westbury, 2011). Additionally, use of multiword expressions by language learners has been associated with patterns of increased fluency (Wood, 2007, 2010). The association that multiword expressions have with fluency suggests that processing efforts can be reduced by using well-known expressions. Therefore, multiword expressions offer potential support for language learners as they strive to express themselves more fluently and understand the speech of others spoken at a natural pace.

Multiword expressions are so prevalent in English that, in order to develop any degree of fluency, a learner needs to have a grasp on the most common multiword expressions for the situations they intend to use the language in. One might assume that language learners will naturally encounter and learn frequent word sequences through typical classroom activities, without any need to have explicit attention drawn to the sequences. Indeed, it has been shown that implicit learning can occur for word combinations that occur 15 times within a single graded reader (Webb, Newton, \& Chang, 2013). However typical graded readers and classroom materials seldom reuse the same language so frequently. The learning process is instead often triggered by drawing attention to form or raising awareness of language phenomena (see Schmidt, 2001).

Boers et al. (2006) found that learners trained during an EFL course to notice multiword expressions were afterwards able to reuse multiword ex- 
pressions from a new text that they were asked to discuss in their posttest, and thus come across as more fluent than the control group. The evidence suggests that multiword expression identification training gave the experimental participants the strategic ability to identify and reuse multiword expressions from the input in their own speech. However, this does not necessarily mean that the experimental participants acquired the multiword expressions they had engaged with in the course materials. In a follow-up study by the same research team, using similar materials and procedures for engaging learners with multiword expressions in input texts, tests were administered to compare participants' knowledge of multiword expressions before and after the course. No difference in knowledge gain was found between the experimental group and the control group, suggesting that the teacher-led noticing activities made little difference for these learners' development of multiword expression knowledge (Stengers, Boers, Housen, \& Eyckmans, 2010).

Awareness-raising in fluency strategies has also been shown to increase fluency. In a 4-week study by Tavakoli, Campbell, and McCormack (2016), participants were trained in general speaking and listening skills while studying abroad in an immersion environment. The experimental participants also received awareness raising instruction in fluency strategies; they were taught to use lexical fillers such as "let me think" and given opportunities to practice such fluency strategies. While all participants improved on the fluency measures, the experimental group was found to speak significantly faster or with greater fluency than the control participants, suggesting that focused strategy and fluency training is worthwhile.

Another way to notice multiword expressions is through text reconstruction exercises, such as dictogloss (Wajnryb, 1990), where a text is heard and learners are tasked with taking notes and then reconstructing it cooperatively. In order to notice multiword expressions, this activity can be adapted by providing the target sequences and requiring participants to fill in the surrounding words. In a study by Lindstromberg, Eyckmans, \& Connebeer (2016), this adaptation was shown to improve participant ability to remember and write the target sequences.

Remembering is indeed important for language learning, and memorization in particular is well known to assist the language learning process (Ding, 2007). Indeed, acquiring a second language has been described as "a process whereby controlled, attention-demanding operations become automatic through practice" (McLaughlin, 1990, p. 125). Simple verbatim memorization can help a language learner speak fluently, as shown in Wray (2004), where a television presenter memorized a cooking recipe in a foreign language (Welsh) to present on a television program. The television presenter was able to present the recipe very fluently in Welsh, despite not having previous knowledge of the language. In fact, language learners appreciate memorizing dialogues as part of the language learning process; at least that was the case 
for $89 \%$ of 146 learners of Japanese in Singapore, who found that memorization of dialogues provided them with a base and structure to use when faced with similar conversations (Walker \& Utsumi, 2006). Memorized dialogues and learning of grammatical chunks in Japanese as a foreign language (at an elementary level) has also been associated with increased language complexity, though not increased fluency (Taguchi, 2007). Although learning the grammatical structure of a multiword expression in English creates grammatical awareness, it is memorization that produces the ability to use it ( $\mathrm{Yu}$, 2009).

Repetition or repeated encounters have long been associated with learning. Knowledge of single words increases with repeated encounters (Horst, Cobb, \& Meara, 1998; Webb, 2007). Collocation or multiword expression knowledge also increases with repeated encounters (Webb et al., 2013). It is therefore likely that repeated practice or use of multiword expressions will also lead to greater learning. Repeatedly shadowing an audio can help multiword expressions enter the phonological loop; Shiki, Mori, Kadota, and Yoshida (2010) found that shadowing between four to five times allowed learners to increase their reproduction rate to a ceiling point. Gatbonton and Segalowitz $(1988,2005)$ apply the concept of repetition through simulated communicative situations that create opportunities for repeated free use of appropriate multiword expressions by learners (as opposed to repeating target multiword expressions in a drill-like fashion after the teacher). This is claimed to stimulate and support automatic retrieval and use of the utterances. Repetition of a monologue on the same topic under increasing time pressure has been linked with increased fluency (Nation, 1989; Thai \& Boers, 2016), and in particular repetition of sentence structures (or multiword expressions) within the monologues has been suggested as the reason for increase in fluent performance (see de Jong \& Perfetti, 2011).

Most of the above studies focused on a particular intervention and its potential for multiword expression learning and or fluency development. This is necessary in research endeavours that wish to measure the effect of a single variable and thus need to control for other variables. In actual pedagogic practice, however, several interventions are typically combined as part of a broader package of classroom procedures, and it is therefore also worth exploring the effectiveness of such a broader package. Combining activities believed to foster fluency such as shadowing, dictogloss, and task repetition under increasing time pressure, among others, Wood (2009) introduced the "fluency workshop," which aimed to give learners multiple practice opportunities with target multiword expressions. It is claimed that in order to develop fluency, activities should be meaning-focused, use familiar language, and be performed under time pressure (Nation, 2014; Nation \& Newton, 2009). The sequence of activities in the fluency workshop progressively builds familiarity with target expressions through repeated use in meaning-focused and 
time-pressured activities. Therefore the fluency workshop seems to fit the fluency criteria set out above.

The results reported from the fluency workshop by Wood (2009) were limited to one Japanese learner studying English in Canada while living in a home-stay situation, with perhaps a reasonably high English proficiency. As a case-study, the results showed an increase in spoken fluency $(13.8 \%$ increase in speech rate), which was associated with the practice and use of target multiword expressions (use of target multiword expressions increased from $11.8 \%$ to $36 \%$ ). However, without a broader sample or a comparison group, one cannot be certain that the fluency gains were a result of the fluency workshop alone. Perhaps simply participating in a general English class without an explicit focus on learning multiword expressions would produce similar results. Using the fluency workshop model from Wood (2009) with 30 Japanese students in Japan, Onoda (2014) also found increases in measures of fluency, but did not report a measure of the use of multiword expressions. Onoda's (2014) study was also reported without a comparison condition, making it impossible to say whether the fluency gains would have been any greater than using a different language learning method.

The fluency workshop concept holds latent potential for classroom language learning situations where fluency interventions are necessary. However, teachers are unlikely to adopt new teaching practices without strong evidence to show that they are more effective. In order to furnish compelling evidence of the effectiveness of the proposed fluency workshop for building speaking fluency and knowledge of multiword expressions, it must be tested with more learners and its outcomes compared with a control group (language learners of comparable ability who experience the pre- and posttests, and spend the same amount of time in language classes over the experimental period but without a focus on speaking using the target multiword expressions; for more information regarding the difference between comparison groups and control groups see Loewen \& Plonsky, 2016, p. 29). Therefore, the current study takes the concept of the 6-week fluency workshop and measures its effectiveness for building speaking fluency with multiword expressions in an EFL environment in Japan and compares results with a control group.

The following research questions were investigated:

1. Does the fluency workshop increase knowledge of target multiword expressions more than a general English class?

2. Does the fluency workshop increase spoken fluency more than a general English class?

3. Does the fluency workshop increase use of multiword expressions in speech more than a general English class?

4. Is there a relationship between fluency and use of multiword expressions? 


\section{Method}

\section{Participants}

The participants $(N=73)$ in this quasi-experimental study came from intact compulsory English classes in an engineering university in Japan. In order to test the influence of the fluency workshop, participants were split into experimental $(n=44)$ and control groups $(n=29)$ using class groupings for logistical reasons. There were only 23 observations for the spoken data analysis due to each observation containing two speakers and only using data from speakers partnered with the same partner at both pre- and posttest sessions. An initial language learning background survey asked participants to self-report their latest score on the Test of English for International Communication (TOEIC), which is a commonly used proficiency measure in Japan, along with other background information. In general, the students' proficiency in English could be described as low, with 16\% reporting a score range of TOEIC 10-250 (IELTS 0-1.5), 52\% reporting TOEIC 255-400 (IELTS 2-3.5), 29\% reporting TOEIC 405-600 (IELTS 4-5), and 3\% reporting TOEIC 605-780 (IELTS 5.5-7).

Ethics approval was sought and approved from research committees at both institutions in Japan and New Zealand. Participants were informed about the nature of the study in writing in Japanese. Participation in the study was voluntary, and informed consent was sought in the first questions of the survey. Participants had the option to allow or not allow use of their pre- and posttest data in the reported research. Only data from those who gave consent were included in the analysis.

\section{Materials}

Materials for the experimental condition were chosen and developed to help build basic ability to communicate using English in three particular travelrelated situations: (a) deciding what to order at a café, (b) giving directions on the street, and (c) making a walk-in reservation and subsequently checking in at a hotel. A model dialogue for each situation was created by the researcher and the vocabulary profile checked using Compleat Lexical Tutor v.8.3 (Cobb, 1994), to ensure predominant use of high-frequency vocabulary. The model dialogues were then double-checked by another native English speaker for naturalness and flow. See Appendix A for the three model dialogues and vocabulary profiles.

Each model dialogue included 10 target multiword expressions (four words in length) that were to be pre- and posttest items. These target multiword expressions were chosen from within the model dialogues, resulting in 30 target expressions in total. Common usage of the target multiword expressions was checked with frequency data from the spoken Corpus of Global Web-Based English (Davies, 2013). Of the selected expressions, 29 occurred 
between 0.03 and 124 times per million words; one further expression, I usually only have, did not occur in the spoken corpus, but since it was intuitively considered a common expression, it was searched for using the Google search engine, resulting in 1,200,000,000 hits. This result was taken as evidence of common use. Rather common expressions were included in target expressions along with less common ones, in order to provide a range for learners to demonstrate knowledge and learning without discouragement nor ceiling effects. A list of the 30 target expressions along with their frequency information is shown in Appendix B. The model dialogues were audio-recorded and used for listening activities in class, and transcripts were also given to participants for reference.

There were some differences between the fluency workshop that Wood reported and this fluency workshop. Whereas the original fluency workshop was conducted in Canada with a participant in a homestay setting, this new fluency workshop was conducted in a small town in Japan with learners who had much less exposure to English language outside of class. The proficiency of the learner in the original fluency workshop was likely to be much greater than the new fluency workshop participants. The original workshop used monologues for models and recordings, while the new workshop used dialogues (as dialogue fitted well with the communicative goals of the course). The original workshop study was a case study of one learner, whereas the new workshop was a quasi-experimental study with a greater number of experimental participants and included a group of control participants of comparable English proficiencies. The differences are further explained in Table 1 and in the following explanation of the experimental classroom activities.

Table 1

Differences Between Current Study and Wood (2009)

\begin{tabular}{ll}
\hline Current study & Wood (2009) \\
\hline Spoken observations $(n=23)$ dialogue & Spoken observations $(n=1)$ narrative \\
Dialogue model & Narrative model \\
Phrase instruction in English and L1 & Phrase instruction in English only \\
Shadowing frequency four times & Shadowing frequency eight times \\
Dictogloss with MWEs printed & Dictogloss \\
Role-play train & Narrative chat circle \\
2-1.5-1 Decreasing time role-play & 4-3-2 Decreasing time narrative \\
\hline
\end{tabular}

All classroom instructions were given verbally, but also reinforced visually in written form with PowerPoint slides. English was the predominant language of instruction, but Japanese was also used at times to enhance understanding, as all learners were native or very proficient Japanese speakers (there were several international students from China participating). 


\section{Classroom Activities: The Experimental Group}

The target expressions were read, heard, written, and spoken multiple times in experimental classroom activities once a week over 6 weeks in the order listed in Table 2. It took two 90-minute classes to cover each topic, so each weekly class generally included five of the activities in the workshop; the following week the class would continue with the remaining activities for the topic. The sequence of the activities flowed from input through to practice and free production.

Table 2

Fluency Workshop Activities in Sequential Order

\begin{tabular}{llll}
\hline 1 & Listen with gist questions & 6 & Mingle jigsaw \\
2 & Marking pauses & 7 & Role-play train \\
3 & Phrase instruction & 8 & Decreasing time role-play \\
4 & Shadowing & 9 & Record role-play \\
5 & Dictogloss & 10 & Free related situation role-play \\
\hline
\end{tabular}

1. Listen with gist questions: In this warm-up activity, participants were familiarized with the model scenario by listening to the model dialogue and then asking and answering several gist questions orally with partners. Participants were given the opportunity to consider and answer questions quietly with a partner to gain confidence in their understanding before any class-level answers were requested. This was then followed by the teacher eliciting class-level answers to the questions.

2. Marking pauses: In this activity participants listened twice more to the audio and were encouraged to notice the rhythm and flow of the conversation by indicating in the transcript any audible pauses in the flow of the words by marking them with a diagonal line between words. They then compared their transcript markings with a partner, before seeing suggested pause markings on the PowerPoint slides. Suggested pause markings were given as a guide, and participants told that variation to this was acceptable.

3. Phrase instruction: In this activity, students were guided by the teacher to notice the target phrases in the transcript through highlighting or underlining them. The highlighted phrases were shown on the PowerPoint slide first within the transcript and then separately with their associated function and meaning. The teacher gave verbal explanation of the meaning and function for each phrase and guided participants to notice that these phrases occurred between pauses in the transcript. Students then shadowed pronunciation for each multiword expression twice after the teacher, in order to familiarize them phonetically with the target multiword expressions. 
4. Shadowing: To further familiarize students with the flow, rhythm, and pronunciation of the phrases within the context of the dialogue, they listened to the audio four more times, using individual headsets and shadowing the entire dialogue at their own pace. The teacher demonstrated the first lines, and students were to speak the words just after the model audio with the transcript in hand for reference. It should be noted that shadowing was done eight times in a language laboratory in the Wood (2009) fluency workshop. However, in light of the aforementioned findings by Shiki et al. (2010) and the desire to not take more time than necessary in class with this activity, it was decided that four times would be sufficient.

5. Dictogloss (Lindstromberg et al., 2016; Wajnryb, 1990): In order to take the pushed output from oral mode to writing mode, the well-known activity of dictogloss was used. Students received a hand-out with the 10 target expressions from the dialogue printed on it with space to fill in the surrounding text that they heard. They listened to the audio four to five times in total as a class. In the first three listenings they took notes and compared notes in pairs, and after the fourth listening they worked to reconstruct the text with a small group of three to six people. Finally, they compared their reconstructions with the original transcript.

6. Mingle jigsaw (Wood, 2009): The mingle jigsaw activity requires students to hold the target phrases in their memory for a short time. Holding language in memory (phonological loop) for a short time and then producing it from memory (articulatory rehearsal) encourages learners to remember the language in chunks (making associative connections) (Ellis, 2001). Mingle jigsaw was conducted as follows: Each person was given a small slip of paper containing a multiword expression that they were instructed to write down and memorize. The small papers were then collected. The teacher demonstrated asking another person what their phrase was and then telling that person her phrase. After this interaction, each person returned to their desk and wrote down the other person's phrase before repeating the sequence with a different person. After this demonstration, everyone stood up and mingled, telling others their phrase and hearing phrases from others. They returned to their desk after each interaction to write down the phrase while they could still recall it. This process was repeated until the time finished or until they had collected and written down all 10 phrases in their list.

7. Role-play train: After learners had listened to the audio multiple times and noticed and practiced saying the phrases through the preceding activities, the next phase pushed them to practice using the phrases in the context of the model dialogue. Learners stood up and made two lines, facing each other as partners. They acted out the model role-play, referring to their 
transcript with their partner. After everyone had completed the role-play, the learners moved down the line so that everyone acquired a new partner and repeated the role-play. This was repeated three times, and then the lines swapped roles, and the role-play was repeated another three times. In total, each person completed the role-play six times (three times in each role).

8. Decreasing time role-play (adapted from 4-3-2 activity, Maurice, 1983): Fluency activities are those in which there is time pressure to perform or communicate using familiar language (Nation \& Newton, 2009). The decreasing time role-play encouraged learners to perform the role-play without notes and under time pressure. A large countdown timer was projected onto the two screens at the front of the class. Learners acted out the role-play in pairs without notes. They had two minutes the first time; they then changed partners and completed the role-play a second time in only one and a half minutes; they changed partners again and acted out the role-play a third time, with only one minute to complete the role-play. They then switched roles and repeated the process.

9. Record role-play: Learners recorded their role-play on the computer without notes and uploaded it to the course Moodle page. This was a fluency activity as they were again under time pressure and dialoguing without notes. The activity also gave them the opportunity to listen to their performance and reflect on their conversation. They were encouraged to listen to the recording to check that their voice could be heard. The recording remained available online on the Moodle class page for students to listen to whenever they liked.

10. Free related situation role-play: In order to give participants the opportunity to broaden their experience using the target phrases, they were provided with a scenario related to the model and instructed to role-play freely with their partner, trying to use the target multiword expressions in their conversation where possible.

\section{Classroom Activities: The Control Group}

The control group experienced the pre- and posttests, and they spent the same amount of time in English classes as the experimental group. However, they were not deliberately exposed to the target multiword expressions, nor were the classroom activities similar. They studied engineering topics in English through linked skills: reading, listening, writing, and speaking on each topic. In this way, the control group progressively built familiarity with the topics and related vocabulary. Language learning through such linked skills progression has also been recommended as an effective way to build fluency (see Nation, 2014). 


\section{Testing the Effects}

At the beginning of the 6-week period of this study, participants completed informed consent, a language learning background survey and pretests. The research questions were investigated using a pre- and posttest design. Pretests consisted of (a) a multiword expressions cloze test designed to test knowledge (productive recall) of target multiword expressions (see Appendix C.1 for a screenshot of the Moodle test page and a text version of the multiword expression pre- and postcloze test), and (b) a spoken role-play recording designed to measure productive oral fluency and use of target multiword expressions. Appendix C.2 shows the instructions that were given for the role-play pre- and posttest. At the end of the 6 weeks, the same tests were administered as posttests, in order to measure learning effects of the treatments.

The multiword expression cloze test was used to measure knowledge of the 30 target multiword expressions (each four words long). Participants had 10 minutes to complete the test via a quiz module on the class Moodle site and were encouraged to skip items they did not know, since the test time was limited. The test format gave participants a short one- to two-sentence context in English in which the gapped expression appeared. The first letter for each component word in the target expression was given, and participants were to complete the missing parts. Note, however, that single-letter words such as ' $I$ ' were given rather than gapped. A Japanese language translation of the expression was also given to help guide their attempt to write the expression in English.

For example:

$$
\begin{aligned}
& \mathrm{H} \_\mathrm{d} \_\mathrm{y} \_\mathrm{s} \_ \text {your name? } \\
& \text { お名前の綴りをお伺いできますか? }
\end{aligned}
$$

The spoken role-play recording was used to measure and analyze spoken fluency and use of target multiword expressions before and after the 6-week treatment period. Participants were asked to audio-record their dialogue on a computer with their partner once before the treatment and again after the treatment. Partners were assigned randomly through shuffled name card seating. The dialogue was to be a role play in which they were looking at a menu in a café and talking about what they would like to order. Participants were given four minutes to record their dialogue.

\section{Surveys and Focus Groups}

In addition to the pre- and posttests, experimental participants completed feedback surveys for each activity (an example of the survey format can be found in Appendix D). These surveys were administered after the final ex- 
perience with each activity of the fluency workshop. Participants were presented with a statement regarding the usefulness of the activity for practicing English and could select the degree to which they thought the statement to be true on a 5-point Likert scale $(1=$ strongly disagree, $5=$ strongly agree $)$. Participants could also write comments regarding the activities on the survey form. In order to further understand student sentiment regarding the activities, volunteers from the experimental group were recruited to participate in a 30-minute focus group discussion outside of class time, to discuss their experience with the activities.

\section{Data Analysis}

The multiword expression cloze test included all 30 target multiword expressions. Scoring was automated so that only completely correct answers for a whole multiword expression were accepted; therefore the maximum possible score was 30 . These scores were then transferred to SPSS for statistical analysis.

The spoken role-play recordings were uploaded to a class Moodle forum. Transcription and analysis of the recorded role-plays only took place where (a) both speakers had consented to have their data analyzed, (b) the partners were the same for both pre- and posttest, and (c) the audio was audible. There were 23 sets of pre- and post-recordings that met these three criteria: 15 from the experimental group and 8 from the control group. Dialogues were analyzed as partner interactions, which means the utterances of the individuals were not separated but kept together for analysis. Therefore, each case number in the statistical analysis actually combines the utterances of two people. Trimmed speech rate, as a composite measure that indicates speed of delivery (inclusive of pausing), was the measure of fluency used in this study since overall fluency was the focus of this study (see Tavakoli et al., 2016). All numbers and words were spelled out in the transcriptions in order to enable accurate counting of syllables for the speech rate. The dialogues were trimmed of all repetitions, fillers, and false starts for this analysis. Word and syllable count was done using the online site http://www.syllablecount. com/\#results. Speaking time was counted until after the last utterance measured in seconds using Windows Media Player. Total syllable count was then divided by the seconds and multiplied by 60 to give the trimmed speech rate of syllables per minute.

In order to count the use of multiword expressions, Antconc (Anthony, 2014) was used to search for sequential words from the multiword expressions in the transcripts using the concordance word search function, first by four words, then by three-word and two-word combinations. This type of search showed use of the target multiword expressions and also revealed related or inaccurate use of the target multiword expressions. Each word used from a target multiword expression in a two or more word combination 
to express the target multiword expression meaning or a related meaning was given one point, enabling partial use of multiword expressions to be measured. For example, if the target multiword expression was I think I will, and a participant said I think that one, then the utterance would be counted as two points because it consisted of two of the four target words in sequence ( $I$ think). However, we will would not be counted as it does not include two sequential words from the target multiword expression I think I will. Multiword expression use was quantifiably measured in this way. As the spoken roleplay recording was based on a café scenario, it was unlikely that participants would use multiword expressions related to giving directions or booking a hotel, which they had also been exposed to. Therefore, it is probably fair to say that the role-play was only likely to draw out 10 of the 30 possible target expressions, or a total of 40 points (10 x 4 words).

The activity feedback surveys were analyzed using SPSS, and activities ranked in order of average perceived usefulness scores. The focus group discussions were audio-recorded and themes noted using ELAN software.

\section{Results}

The experimental and control group scores did not differ significantly in any of the pretests, suggesting comparability on these measures at the beginning of the experiment. After 6 weeks, the same tests were administered to compare any changes in (a) performance on the cued recall test, (b) fluency, and (c) quantities of target multiword expressions used in the recorded dialogues. The relationship between fluency and quantity of target multiword expressions used was then investigated by correlating the fluency scores and use of target multiword expressions. Also, at the end of the study the learners' feedback on the workshop activities was collected to determine if any adjustments to the workshop were desirable for its further implementation in the given context.

Results from the multiword expressions cloze test can be seen in Table 3. It was clear from this test that productive knowledge of target expressions had increased significantly more for the experimental group $(n=44) M=7.63, S D$ $=4.12$, than for the control group $(n=29) M=2.55, S D=3.01, t(71)=-5.71, p=$ $.000, d=1.41$. While the relatively high standard deviations indicate a range of uptake, these results suggest that the fluency workshop helped learners to connect meaning to form and to be able to write the form of the multiword expression when prompted with the Japanese language equivalent and the first letters of each word in English. 
Table 3

Study 1 Multiword Expression Cloze Test Results

\begin{tabular}{llll}
\hline & $\begin{array}{l}\text { Pretest } \\
\text { Multiword expression } \\
\text { score }(30)\end{array}$ & $\begin{array}{l}\text { Posttest } \\
\text { Multiword expression } \\
\text { score }(30)\end{array}$ & Increase \\
\hline Experimental $(n=44)$ & $8.95(S D=3.42)$ & $16.58(S D=5.19)$ & $7.63(S D=4.12)$ \\
Control $(n=29)$ & $10.00(S D=3.89)$ & $12.55(S D=5.07)$ & $2.55(S D=3.01)$ \\
\hline
\end{tabular}

Fluency was measured by trimmed speech rate (meaningful syllables uttered per minute). Recall that the spoken data set concerns a smaller number of participants than the cloze test as only those who met the criteria stipulated in the data analysis were included. A repeated measures ANOVA showed a significant main effect for trimmed speech rate $F(1,21)=4.94, p=.037, \eta^{2}=.19$. This means that there was a significant overall increase in speech rate regardless of condition. However, the interaction between treatment and speech rate (the difference in increase between the two groups) was not statistically significant $F(1,21)=0.454, p=.51, \eta^{2}=.02$. This means that the two conditions did not differ in the degree to which their trimmed speech rate increased. Table 4 shows the average pre- and posttest trimmed speech rates by group with confidence intervals. In Wood (2009), speech rate increased by $13.8 \%$ : (posttest score - pretest score)/pretest score $\mathrm{x} 100$. In comparison, the experimental group's speech rate in the present study increased by $23.3 \%$, a significant increase according to a paired samples $t$-test, $t(14)=3.28, p=.006, d=0.63$, and the control group increased by $12.3 \%, t(7)=-0.70, p=.507, d=0.34$.

Table 4

Trimmed Speech Rate in the Pre- and Posttest

\begin{tabular}{lllllll}
\hline $\begin{array}{l}\text { Trimmed } \\
\text { speech rate }\end{array}$ & $\begin{array}{l}\text { Pretest } \\
\text { mean }\end{array}$ & $S D$ & $95 \% \mathrm{Cl}$ & $\begin{array}{l}\text { Posttest } \\
\text { mean }\end{array}$ & SD & $95 \% \mathrm{Cl}$ \\
\hline $\begin{array}{l}\text { Experimental } \\
(n=15)\end{array}$ & $\mathbf{4 7 . 0 3}$ & 16.39 & $37.20,56.85$ & $\mathbf{5 7 . 9 5}$ & 18.49 & $49.12,66.77$ \\
$\begin{array}{l}\text { Control } \\
(n=8)\end{array}$ & 47.73 & 21.62 & $34.30,61.19$ & 53.57 & 11.25 & $41.49,65.66$ \\
\hline
\end{tabular}

Note. Bold font indicates significant difference at 0.025 (Bonferroni corrected)

The quantities of target multiword expressions used in the role-play are shown in Table 5. Gain scores in pre- to posttest target multiword expression use were calculated and an independent $t$-test showed no significant difference between the experimental group and the control group, $t(21)=-.877, p=$ $.391 ; d=0.41$. Wood (2009) found use of target multiword expressions (those used in workshop models) increased by $24 \%$. In the current study, the roleplay drew on 10 potential target multiword expressions of four words each, so the maximum total score was 40 . The experimental pairs increased their 
multiword expression use by $12 \%, t(14)=-2.19, p=.046, d=0.22$., while the control pairs increased by $4.7 \%, t(7)=-.96, p=.368, d=0.35$.

Table 5

Multiword Expression Use in the Pre- and posttest

\begin{tabular}{|c|c|c|c|c|c|c|}
\hline $\begin{array}{l}\text { Multiword } \\
\text { expression use }\end{array}$ & $\begin{array}{l}\text { Pretest } \\
M\end{array}$ & $S D$ & $95 \% \mathrm{Cl}$ & $\begin{array}{l}\text { Posttest } \\
M\end{array}$ & $S D$ & $95 \% \mathrm{Cl}$ \\
\hline $\begin{array}{l}\text { Experimental } \\
(n=15)\end{array}$ & 6.20 & 4.07 & $3.53,8.87$ & 11.00 & 7.34 & $7.55,14.45$ \\
\hline Control $(n=8)$ & 5.00 & 6.41 & $1.34,8.66$ & 6.88 & 3.98 & $2.16,11.59$ \\
\hline
\end{tabular}

It was hypothesised that fluency (trimmed speech rate) and use of multiword expressions would be positively correlated, and this is borne out by the data. Taking all 23 dialogues together, speech rate and use of multiword expressions were positively correlated in the pretest at $r=.484(p=.019)$, and in the posttest at $r=.237$ (but the latter correlation fell short of significance: $p=.275$ ). Also when the increase in fluency (speech rate) was related to the increase in the use of multiword expressions (regardless of group), a positive correlation was found, though this fell short of significance, $r=.31 ; p=.149$.

Finally, the activity feedback survey results (Table 6) showed that participants considered phrase instruction $(M=4.21, S D=0.71)$ and shadowing $(M=3.84, S D=0.92)$ to be the most useful activities; there was no significant difference between their rating, $t(33)=-1.66, p=.107$. Role-play with notes $(M=3.78, S D=0.85)$ was considered the next most useful activity with a rating that differed significantly from phrase explanation, $t(29)=-2.56, p=.02$. The lowest rated activity was mingle-jigsaw $(M=3.42, S D=0.15)$, which was rated significantly lower than role-play, $t(30)=2.27, p=.03$. The focus groups looked at the average ratings for each activity and discussed potential reasons

Table 6

Perceived Usefulness of Activities for Practicing English

\begin{tabular}{ll}
\hline Phrase instruction & 4.21 \\
Shadowing & 3.84 \\
Role-play & 3.78 \\
Marking pauses & 3.62 \\
Decreasing time role-play & 3.57 \\
Record role-play & 3.51 \\
Free role-play & 3.47 \\
Dictogloss & 3.43 \\
Mingle jigsaw & 3.42 \\
\hline
\end{tabular}

Note. 1 = strongly disagree; 5 = strongly agree. 
for the ratings. In particular, marking pauses stood out as an activity that participants struggled with. All three participants in the focus group discussion stated that "the sound is too fast," and one participant's comment sheds further light on this complaint: "to be honest I cannot hear the pauses." So it was noted that pauses were hard to distinguish, particularly as the model dialogues were in short turns. Marking pauses appeared to be an activity that was perhaps not as useful for conversational dialogue as it might have been for monologue narrative (as in Wood, 2009).

Another activity that stood out in focus group discussions was the roleplay recording; without time allocated in class to listen and without a structure for reflection, the focus group participants said that they were not likely to listen again even though the recording was available to them on the online class Moodle page. One participant stated, "If there was an opportunity to listen to it, it would be useful," thereby suggesting the need to allocate class time for self-reflection on the recording.

\section{Discussion and Implications}

This study set out to investigate four research questions that will now be discussed in light of the results. The first research question asked whether the fluency workshop increased knowledge of target multiword expressions. Based on the multiword expression cloze test, we can say that the fluency workshop did increase knowledge (expressed through cued recall) of the expressions. Despite the experimental group and the control group showing similar levels of productive multiword expression knowledge on the pretest, the experimental group showed significantly more knowledge of the multiword expressions in the same test 6 weeks later when compared with the control group. The fluency workshop obviously increased participants' knowledge of multiword expressions, more so than a general English class.

The second research question asked if the fluency workshop increased spoken fluency more than a general English class. Those who participated in the fluency workshop significantly increased their speech rate from the pre- to the posttest, and such an increase was not present among the control participants. However, no statistical difference was present between the two groups in the posttest. It should be noted that with smaller sample sizes for the spoken data, the effect of the experiment would have had to be remarkable in order to be detected inferentially. Results suggest that the fluency workshop increases spoken fluency, and further investigation with more participants is necessary to compare the effects of the fluency workshop more statistically. These results do, however, highlight the importance of including a comparison or control group in an experimental study. Without such a comparison, we could say that our participants significantly increased their knowledge and fluency on several measures, but when this difference is shown to be no more than a control group, we must question whether the effort required to 
implement the fluency workshop, or the reduction in other language learning areas that occurred to make room for the fluency workshop, is validated. Deciding whether to implement the fluency workshop in a classroom needs to be considered in relation to language learning goals. While it may appear to enhance fluency, it is possible that the fluency gain may actually be no greater than other language learning methods when compared statistically.

The third research question asked if the fluency workshop increased use of multiword expressions in speech more than a general English class? The results from this study showed no statistical difference between use of multiword expressions in the experimental group and the control group (our general English class). When the descriptive statistics are considered alone, the increase for the experimental group seems clear; however, this increase was not marked enough to show when analyzed inferentially. The disparity between knowledge of multiword expressions (as shown in the cloze test) and use in conversation could reflect the incremental nature of learning multiword expressions and perhaps suggests that productive recall precedes free productive speaking use. It could also be a reflection of the test type, in that the role-play did not directly prompt the use of the target multiword expressions or necessitate their use, whereas the cloze test did.

The fourth research question asked whether there was a relationship between fluency (speech rate) and use of multiword expressions. The results from the pretest showed a positive correlation between speech rate and use of multiword expressions, but statistical significance was not reached in the posttest results or with the relationship for increase in both measures. So while the data from this study seems to suggest the presence of a relationship, it does not confirm it.

Although it needs to be acknowledged that students may not be able to accurately assess the effectiveness for language learning of classroom activities, it is important to gauge their reactions to what they are asked to do in the classroom, as it affects their attitude or affect toward positive classroom participation. Student feedback on the activities offered suggestions for improving the fluency workshop to fit better with the context and learners. In particular, marking pauses stood out as an activity that added little value when listening to short-turn conversational dialogue and could perhaps be removed from the workshop activity set. Removal of the marking pauses activity would allow time to be allocated to structured reflection after the role-play recording during class time. Inclusion of this reflection time would ensure that learners listen to their role-play recordings and reflect on their fluency.

Returning to the need to verify the effectiveness of this set of fluency activities for building speaking fluency and knowledge and use of multiword expressions, the fluency workshop certainly appears to improve recall of multiword expressions, which shows development of productive knowledge, which with practice should lead to increased use of multiword expressions in 
dialogue and increased speech rate. The advantage that the fluency workshop has for building knowledge of multiword expressions is clear-the challenge lies in encouraging learners to use the multiword expressions they know in conversation.

\section{Limitations and Future Research}

This preliminary study is not without limitations, the first being the limited sample size for spoken dialogue analysis that may be hiding what would otherwise have been significant differences between the experimental and control groups. Another limitation is that the analysis of the spoken dialogues would become more precise if the dyads were able to be split for analysis. Unfortunately, individuals were not able to be distinguished from the audiorecording as they did not self-identify at the beginning of the recording.

Future investigations into fluency within the context of conversation needs to be able to separate conversation partners and analyze their speech separately in order to see the effect of the treatment more clearly. This could be done through clear identification at the beginning of the dialogue, or through video-recordings so that the speaker can be visually identified. Also, the spoken role-play allowed speakers to avoid using the target multiword expressions. A test format in which they are forced to show their ability to use the target multiword expressions would be preferable, though difficult when the aim is to simulate a natural conversation.

Participant feedback suggested that some activities might become more effective with slight adjustments. For example, while participants were encouraged to listen to their recording and reflect on their fluency, the time and structure to do this was not given in class, so it is likely that most did not actually listen and reflect. In light of this, allocating class time for reflection and giving it more structure may potentially boost the effectiveness and credibility of the recording as a learning activity. This and other such suggestions should be incorporated into future work to improve on the methods of this first study in order to investigate and discover more effective ways to build fluency in the classroom and unpack the relationship between fluency and use of multiword expressions.

\section{Acknowledgements}

This research was made possible with funding and support from Muroran Institute of Technology and Victoria University of Wellington. Many thanks go to the participants who allowed their data to be used for research purposes. I would like to thank Dr. Averil Coxhead and Dr. Frank Boers for their guidance and support in this project as my PhD supervisors. I am immensely grateful to two anonymous reviewers who gave very useful critiques, which allowed me to chisel the original manuscript into a much improved version.

\section{The Author}

Haidee Thomson is an Assistant Professor at Hokusei Gakuen University Junior College in Japan. She is also a PhD candidate in the School of Linguistics and Applied Language Studies at Vic- 
toria University of Wellington, New Zealand. Her research focuses on the relationship between language fluency and use of multiword expressions.

\section{References}

Anthony, L. (2014). AntConc (Version 3.4.3) [Computer Software]. Tokyo, Japan: Waseda University. Retrieved from http://www.laurenceanthony.net/

Boers, F., Eyckmans, J., Kappel, J., Stengers, H., \& Demecheleer, M. (2006). Formulaic sequences and perceived oral proficiency: Putting a lexical approach to the test. Language Teaching Research, 10(3), 245-261. https://doi.org/10.1191/13621688061r195oa

Chambers, F. (1997). What do we mean by fluency? System, 25(4), 535-544. https://doi.org/10.1016/ S0346-251X(97)00046-8

Cobb, T. (1994). Compleat Lexical Tutor v.8.3 (Adaptation of Heatley \& Nation's, 1994, range) [Computer program]. Retrieved from http://www.lextutor.ca/vp/

Davies, M. (2013). Corpus of global web-based English: 1.9 billion words from speakers in 20 countries. Retrieved from http://corpus.byu.edu/glowbe/

de Jong, N., \& Perfetti, C. A. (2011). Fluency training in the ESL classroom: An experimental study of fluency development and proceduralization. Language Learning, 61(2), 533-568. https://doi.org/10.1111/j.1467-9922.2010.00620.x

Derwing, T. M., Munro, M. J., \& Thomson, R. I. (2008). A longitudinal study of ESL learners' fluency and comprehensibility development. Applied Linguistics, 29(3), 359-380. https://doi. org/10.1093/applin/amm041

Ding, Y. (2007). Text memorization and imitation: The practices of successful Chinese learners of English. System, 35(2), 271-280. https://doi.org/10.1016/j.system.2006.12.005

Dörnyei, Z. (2009). The psychology of second language acquisition. Oxford, UK: Oxford University Press.

Ellis, N. C. (2001). Memory for language. In P. Robinson (Ed.), Cognition and second language instruction (pp. 33-68). Cambridge, UK: Cambridge University Press.

Ellis, N. C., Simpson-Vlach, R., \& Maynard, C. (2008). Formulaic language in native and second language speakers: Psycholinguistics, corpus linguistics, and TESOL. TESOL Quarterly, 42(3), 375-396. https://doi.org/10.1002/j.1545-7249.2008.tb00137.x

Erman, B., \& Warren, B. (2000). The idiom principle and the open choice principle. Text, 20(1), 29-62. https://doi.org/10.1515/text.1.2000.20.1.29

Gatbonton, E., \& Segalowitz, N. (1988). Creative automatization: Principles for promoting fluency within a communicative framework. TESOL Quarterly, 22(3), 473-492. https://doi. org $/ 10.2307 / 3587290$

Gatbonton, E., \& Segalowitz, N. (2005). Rethinking communicative language teaching: A focus on access to fluency. Canadian Modern Language Review / La Revue Canadienne Des Langues Vivantes, 61(3), 325-353. https://doi.org/10.3138/cmlr.61.3.325

Horst, M., Cobb, T., \& Meara, P. (1998). Beyond a clockwork orange: Acquiring second language vocabulary through reading. Reading in a Foreign Language, 11(2), 207-23.

Kuiper, K. (1991). The evolution of an oral tradition: Race-calling in Canterbury, New Zealand. Oral Tradition Journal, 6(1), 19-34.

Kuiper, K. (2004). Formulaic performance in conventionalised varieties of speech. In N. Schmitt (Ed.), Formulaic sequences: Acquisition, processing, and use (Vol. 9, pp. 37-54). Amsterdam, Netherlands: J. Benjamins. Retrieved from http://public.eblib.com/choice/publicfullrecord. aspx? $\mathrm{p}=622575$

Lennon, P. (1990). Investigating fluency in EFL: A quantitative approach. Language Learning, 40(3), 387-417. https://doi.org/10.1111/j.1467-1770.1990.tb00669.x

Lindstromberg, Eyckmans, J., \& Connebeer, R. (2016). A modified dictogloss for helping university students notice and remember conventional phrasal expressions of academic English (as L2) and use them in later writing. Journal of English for Special Purposes, (41), 12-21. https:// doi.org/10.1016/j.esp.2015.08.002 
Loewen, S., \& Plonsky, L. (2016). An A-Z of applied linguistics research methods. London, UK: Palgrave Macmillan.

MacIntyre, P., \& Gregersen, T. (2012). Affect: The role of language anxiety and other emotions in language learning. In Psychology for language learning (pp. 103-118). London, UK: Palgrave Macmillan. https://doi.org/10.1057/9781137032829

Maurice, K. (1983). The fluency workshop. TESOL Newsletter, 17(4), 29.

McLaughlin, B. (1990). Restructuring. Applied Linguistics, 11(2), 113-128. https://doi.org/10.1093/ applin/11.2.113

Nation, I. S. P. (1989). Improving speaking fluency. System, 17(3), 377-384. https://doi. org/10.1016/0346-251X(89)90010-9

Nation, I. S. P. (2014). Developing fluency. In T. Muller, J. Adamson, P. S. Brown, \& S. Herder (Eds.), Exploring EFL fluency in Asia (pp. 11-25). Basingstoke, UK: Palgrave Macmillan. Retrieved from https://www.palgrave.com/us/book/9781137449399

Nation, I. S. P., \& Newton, J. (2009). Teaching ESL/EFL listening and speaking. New York, NY: Routledge.

Onoda, S. (2014). An exploration of effective teaching approaches for enhancing the oral fluency of EFL students. In T. Muller, J. Adamson, P. Shigeo Brown, \& S. Herder (Eds.), Exploring EFL Fluency in Asia (pp. 120-142). Basingstoke, UK: Palgrave Macmillan. Retrieved from https:// www.palgrave.com/us/book/9781137449399

Peters, A. M. (1983). The units of language acquisition. Cambridge, UK: Cambridge University Press.

Rossiter, M. J., Derwing, T. M., Manimtim, L., \& Thomson, R. I. (2010). Fluency: The neglected component in the communicative classroom. Canadian Modern Language Review, 66(4), 583606. https://doi.org/10.3138/cmlr.66.4.583

Schmidt, R. (2001). Attention. In P. Robinson (Ed.), Cognition and second language instruction (pp. 3-32). Cambridge, UK: Cambridge University Press. https://doi.org/10.1017/ CBO9781139524780.003

Segalowitz, N. (2010). The cognitive bases of second language fluency. New York, NY: Routledge.

Shiki, O., Mori, Y., Kadota, S., \& Yoshida, S. (2010). Exploring differences between shadowing and repeating practices: An analysis of reproduction rate and types of reproduced words. ARELE: Annual Review of English Language Education in Japan, 21, 81-90. https://doi. org/10.20581/arele.21.0_81

Siyanova-Chanturia, A., Conklin, K., \& van Heuven, W. J. (2011). Seeing a phrase "time and again" matters: The role of phrasal frequency in the processing of multiword sequences. Journal of Experimental Psychology, 37(3), 776-784. https://doi.org/10.1037/a0022531

Siyanova-Chanturia, A., \& Martinez, R. (2015). The idiom principle revisited. Applied Linguistics, 36(5), 549-569. https://doi.org/10.1093/applin/amt054

Stengers, H., Boers, F., Housen, A., \& Eyckmans, J. (2010). Does "chunking" foster chunk-uptake? In S. De Knop, F. Boers, \& De Rycker, A. (Eds.), Fostering language teaching efficiency through cognitive linguistics (pp. 99-117). Berlin, Germany: De Gruyter Mouton.

Taguchi, N. (2007). Chunk learning and the development of spoken discourse in a Japanese as a foreign language classroom. Language Teaching Research, 11(4), 433-457. https://doi. org/10.1177/1362168807080962

Tavakoli, P., Campbell, C., \& McCormack, J. (2016). Development of speech fluency over a short period of time: Effects of pedagogic intervention. TESOL Quarterly, 50(2), 447-471. https:// doi.org/10.1002/tesq.244

Thai, C., \& Boers, F. (2016). Repeating a monologue under increasing time pressure: Effects on fluency, complexity, and accuracy. TESOL Quarterly, 50(2), 369-393. https://doi.org/10.1002/ tesq. 232

Tremblay, A., Derwing, B., Libben, G., \& Westbury, C. (2011). Processing advantages of lexical bundles: Evidence from self-paced reading and sentence recall tasks. Language Learning, 61(2), 569-613. https://doi.org/10.1111/j.1467-9922.2010.00622.x 
Underwood, G., Schmitt, N., \& Galpin, A. (2004). The eyes have it: An eye movement study into the processing of formulaic language. In N. Schmitt (Ed.), Formulaic sequences: Acquisition, processing, and use (Vol. 9, pp. 153-168). Amsterdam, Netherlands: J. Benjamins. Retrieved from http://www.jbe-platform.com/content/books/9789027295750

Wajnryb, R. (1990). Grammar dictation. Oxford: Oxford University Press.

Walker, I., \& Utsumi, T. (2006). Memorizing dialogues: The case for performance exercises. In W. M. Chan, K. N. Chin, \& S. Titima (Eds.), Foreign language teaching in Asia and beyond: Current perspectives and future directions (pp. 243-269). Singapore: Centre for Language Studies.

Webb, S. (2007). The effects of repetition on vocabulary knowledge. Applied Linguistics, 28(1), 46-65. https://doi.org/10.1093/applin/aml048

Webb, S., Newton, J., \& Chang, A. (2013). Incidental learning of collocation. Language Learning, 63(1), 91-120. https://doi.org/10.1111/j.1467-9922.2012.00729.x

Wood, D. (2007). Measuring the link between formulaic sequences and speech fluency: Implications for the language classroom. Contact TESL Ontario, 33(2, Special Research Forum Issue), 97-117.

Wood, D. (2009). Effects of focused instruction of formulaic sequences on fluent expression in second language narratives: A case study. Canadian Journal of Applied Linguistics, 12(1), 39-57.

Wood, D. (Ed.). (2010). Perspectives on formulaic language: Acquisition and communication. London, UK: Continuum.

Wray, A. (2004). "Here's one I prepared earlier": Formulaic language learning on television. In N. Schmitt (Ed.), Formulaic sequences: Acquisition, processing, and use (pp. 249-268). Amsterdam, Netherlands: J. Benjamins. Retrieved from http://public.eblib.com/choice/publicfullrecord. aspx? $\mathrm{p}=622575$

Yu, X. (2009). A formal criterion for identifying lexical phrases: Implication from a classroom experiment. System: An International Journal of Educational Technology and Applied Linguistics, 37(4), 689-699. https://doi.org/10.1016/j.system.2009.09.012

\section{Appendix A. Model Dialogues and Vocabulary Profiles}

\section{Café}

P: Right, Jon. We have about an hour for lunch. The next meeting is at two thirty.

J: That's good. I usually only have time for a quick lunch, often at my desk!

$\mathrm{P}$ : Let's see what they have on the menu. What would you like Jon?

$\mathrm{J}$ : Mmm the salmon looks good, but so does the omelet. What are you going to get?

P: I think I'll have the chicken.

$\mathrm{J}$ : OK, I'll have the salmon.

$\mathrm{P}$ : Shall we get a salad to share?

J: Great idea, and are you going to get a drink?

$\mathrm{P}$ : Mm, I think I'll get a coffee, how about you?

$\mathrm{J}$ : Coffee, yeah me too.

$\mathrm{P}$ : OK, let's order!

Vocabulary profile (VP Classic)

$\mathrm{K} 1: 81.82 \%$ (tokens)

K2: $6.36 \%$

AWL: $0 \%$

Off-list: $11.82 \%$ (jon menu mmm okay omelet salad salmon yeah) 


\section{Directions}

A: Excuse me, how do I get to the National Museum? Can you tell me how?

B: The National Museum, um...go straight along this road, when you get to the traffic lights, turn left onto Green street.

A: Turn left at the traffic lights onto Green street, OK.

B: Then, walk along Green street until you get to the Square. You should see the Museum on the right. The Museum is on the right hand side of the Square.

A: So, I turn left at the traffic lights then go up Green Street until I get to the Square.

$\mathrm{B}$ : Yes, and the Museum is on the right side of the Square.

A: OK. Thank you very much.

B: No worries, have a good day!

A: Thank you! You too!

Vocabulary profile (VP Classic)

K1: $87.40 \%$ (tokens)

K2: $3.94 \%$

AWL: $0 \%$

Off-list: $8.66 \%$ (museum, um, traffic, ok)

\section{Hotel}

Staff: Welcome to the Hotel. How may I help you?

C: l'd like a room please.

Staff: How many are in your party?

C: Just two.

Staff: What type of room would you like? We have doubles and twins available.

C: I'd like a double, please.

Staff: OK, how many nights would you like to stay?

C: Sorry, could you repeat that please?

Staff: Certainly. How many nights would you like to stay?

C: Oh, just tonight.

Staff: OK. May I have your name, please?

C: Timothy Findley.

Staff: How do you spell that please?

C: F-I-N-D-E-...

Staff: Sorry, can you repeat that please?

C: F-I-N-D-L-E-Y

Staff: OK, um that will be $\$ 120$. How will you be paying?

C: Is Visa OK?

Staff: That will be fine.

C: Is breakfast included?

Staff: No, it is an extra $\$ 15$ each. Would you like to add it your reservation?

C: Um, let me think about it. Does the room have WIFI?

Staff: Yes, the details are in your room in the folder on the desk. 
C: OK, thank you.

Staff: Do you have any other questions?

C: Not at this stage, thank you.

Staff: OK, you're in room 405 on the fourth floor. Here's your key. Enjoy your stay.

C: Thank you very much.

Vocabulary profile (VP Classic)

K1: $77.61 \%$ (tokens)

K2: $14.93 \%$

AWL: $0.50 \%$

Off-list: $6.97 \%$ (twins, ok, timothy findley, um, visa, wifi, folder)

Appendix B. The 30 Target Multiword Expressions with Frequency Data

\begin{tabular}{|c|c|c|c|c|c|}
\hline & Unit & $\begin{array}{l}\text { Target multiword } \\
\text { expression }\end{array}$ & $\begin{array}{l}\text { Frequency } \\
\text { profile of } \\
\text { vocabulary }\end{array}$ & $\begin{array}{c}\text { Occurrences } \\
\text { within COCA } \\
\text { spoken words } \\
\text { corpus }(95,565,075)\end{array}$ & $\begin{array}{l}\text { Occurrences } \\
\text { per million } \\
\text { words } \\
\text { (COCA) }\end{array}$ \\
\hline 1 & Cafe & we have about an & $\mathrm{K} 1$ & 59 & 0.62 \\
\hline 2 & Cafe & I usually only have & $\mathrm{K} 1$ & \multicolumn{2}{|c|}{$\begin{array}{c}0 \text { in COCA, but } 1,200,000,000 \text { hits } \\
\text { in a Google Search }\end{array}$} \\
\hline 3 & Cafe & have on the menu & $\begin{array}{l}\text { have on the } \\
\text { (K1) } \\
\text { menu (K2) }\end{array}$ & 5 & 0.05 \\
\hline 4 & Cafe & What would you like & $\mathrm{K} 1$ & 315 & 3.30 \\
\hline 5 & Cafe & but so does the & $\mathrm{K} 1$ & 7 & 0.07 \\
\hline 6 & Cafe & what are you going & $\mathrm{K} 1$ & 1075 & 11.25 \\
\hline 7 & Cafe & I think I will & K1 & 68 & 0.71 \\
\hline 8 & Cafe & I will have the & $\mathrm{K} 1$ & 12 & 0.13 \\
\hline 9 & Cafe & are you going to & $\mathrm{K} 1$ & 4207 & 44.02 \\
\hline 10 & Cafe & to get a drink & $\mathrm{K} 1$ & 18 & 0.19 \\
\hline 1 & Directions & How do I get & $\mathrm{K} 1$ & 78 & 0.82 \\
\hline 2 & Directions & Can you tell me & $\mathrm{K} 1$ & 481 & 5.03 \\
\hline 3 & Directions & When you get to & K1 & 264 & 2.76 \\
\hline 4 & Directions & turn left at the & K1 & 3 & 0.03 \\
\hline 5 & Directions & until you get to & $\mathrm{K} 1$ & 33 & 0.35 \\
\hline 6 & Directions & You should see the & $\mathrm{K} 1$ & 32 & 0.33 \\
\hline 7 & Directions & right hand side of & $\mathrm{K} 1$ & 7 & 0.07 \\
\hline 8 & Directions & until I get to & K1 & 10 & 0.10 \\
\hline 9 & Directions & is on the right & $\mathrm{K} 1$ & 67 & 0.70 \\
\hline 10 & Directions & have a good day & $\mathrm{K} 1$ & 149 & 1.56 \\
\hline 1 & Hotel & How many are in & $\mathrm{K} 1$ & 9 & 0.09 \\
\hline 2 & Hotel & could you repeat that & $\begin{array}{l}\text { could you that } \\
\text { (K1) } \\
\text { repeat (K2) }\end{array}$ & 14 & 0.15 \\
\hline
\end{tabular}




\begin{tabular}{|c|c|c|c|c|c|}
\hline 3 & Hotel & How do you spell & $\begin{array}{l}\text { How do you } \\
\text { (K1) } \\
\text { spell (K2) }\end{array}$ & 13 & 0.14 \\
\hline 4 & Hotel & How will you be & $\mathrm{K} 1$ & 11 & 0.12 \\
\hline 5 & Hotel & That will be fine & $\mathrm{K} 1$ & 7 & 0.07 \\
\hline 6 & Hotel & It is an extra & $\mathrm{K} 1$ & 3 & 0.03 \\
\hline 7 & Hotel & Would you like to & $\mathrm{K} 1$ & 1145 & 11.98 \\
\hline 8 & Hotel & let me think about & $\mathrm{K} 1$ & 21 & 0.22 \\
\hline 9 & Hotel & the details are in & $\begin{array}{l}\text { the are in (K1) } \\
\text { details (K2) }\end{array}$ & 3 & 0.03 \\
\hline 10 & Hotel & Thank you very much. & $\mathrm{K} 1$ & 11859 & 124.09 \\
\hline
\end{tabular}

\section{Appendix C.1. Multiword Expressions Cloze Test}

Moodle screen-shot (each question appeared on a new page)

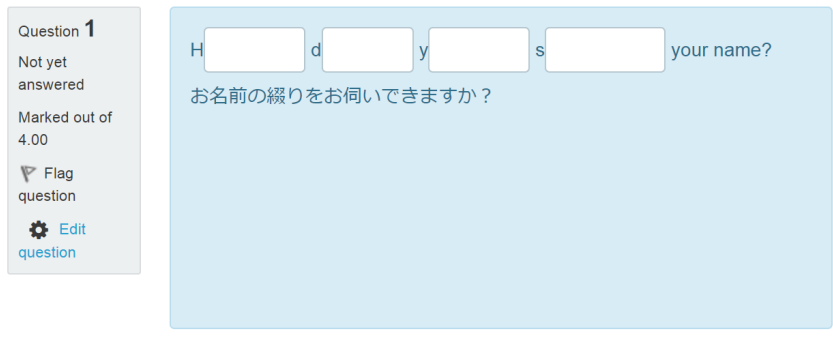

\section{QUIZ NAVIGATION}

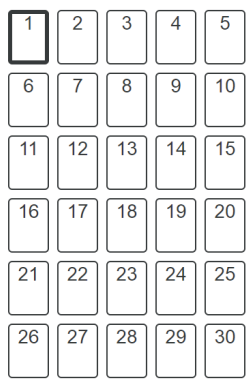

(How do you spell)

(Thank you very much)

(How many are in)

3 Hotel How many are in your party?

グループは何名様でしょうか。

4 Hotel I'm sorry, $\mathrm{c}$ すみません。もう一度おっしゃっていただけますか

5 Hotel $\quad H_{\ldots} w_{\ldots} y_{\text {_ _ }}$ b__ paying?

(How will you be) お支払はいかがなさいますか。

6 Hotel

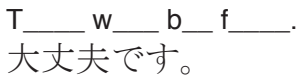

(That will be fine)

7 Hotel

お一人様 15 ドルの別料金になります。 
8 Hotel

W ご予約に追加いたしますか。

9 Hotel $\quad \frac{T}{\text { お部屋に説明書がございます。 }}$

10 Hotel

$\mathrm{L} \_\mathrm{m} \_\mathrm{t}$

検討させてください。

11 Café $\quad$ w_ w_y_ I__ Mike?

マイクさんは何にしますか。

12 Cafe $\quad w_{\ldots} \quad h \_$a__ a_ hour for lunch

お昼休みは一時間程度あります。

13 Cafe Let's see what they $\mathrm{h}_{\text {_ }} \mathrm{o} \_\mathrm{t}$ _ $\mathrm{m}$ _.

メニューに何があるか、見てみましょう。

14 Cafe The salmon looks good, b__ s______ omelet (but so does the) サケが美味しそうですけ、オムレツもおいしそうですね

15 Cafe

w_a_ a_

何を頼みますか。

16 Cafe It_ I w_ have the chicken.

チキンを頼もうかなと思っています

17 Cafe

$\mathrm{OK}, \mathrm{I}$ w__ h_____ salmon.

じや、私はサケにします。

18 Cafe

A_____ g_ t___get a coffee?

コーヒーを注文しますか。

19 Cafe Are you going $\mathrm{t} \_\mathrm{g}$ __a d__ ?

飲み物を注文しますか。

20 Cafe I u_ o__ h__ time for a quick lunch

普段は時間がなくて、簡単なお昼しか取れないです。

21 Directions $\mathrm{H}_{\ldots} \mathrm{d}_{\text {_ }} \mathrm{Ig} \mathrm{g}_{\text {_ }}$ to the train station?

駅はどうやって行きますか

22 Directions

$\mathrm{C}$
郵便局への道を教えていただけますか。

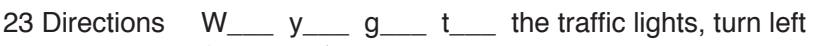

信号に着いたら左にまがってください

(I will have the)

(are you going to)

(to get a drink)

(I think I will)

(What are you going)

T

24 Directions $\begin{gathered}\mathrm{T} \\ \text { 信号で左折する }\end{gathered}$

(turn left at the)

(Can you tell me)

(When you get to)

25 Directions Walk along Green street $\mathrm{u}_{\text {__ }} \mathrm{y}_{\text {__ }} \mathrm{g} \_$____ the Square (until you get to) 広場までグリーンストリートに沿って歩いて

26 Directions $Y_{-} s_{-} s_{-} t_{1}$ Museum on the right.

博物館は右に見えるはずです

27 Directions The Museum is on the $\mathrm{r}_{\text {__ }} \mathrm{h} \_$___ o__ the Square. (right hand side of) 博物館は広場の右手にあります。 
28 Directions So, I turn left at the traffic lights then go up Green Street $\mathrm{u} \_\mathrm{Ig} \_\mathrm{t}$ __ the Square.

(until I get to) では、信号で左折して、そして、広場までグリーンストリー 卜を直進して通ります。

29 Directions The Museum i__ o_____ side of the Square (is on the right) 博物館は広場の右手にあります。

30 Directions No worries, $\mathrm{h}$ a g__ d_

(have a good day) いいえ、よい一日を!

\section{Appendix C.2. Role-play Instructions for Pre- and Posttest}

You are at a restaurant for lunch with your friend.

- Try to talk in English only

- You have 1 hour to order and eat

- Talk about the menu with your partner

- Ask what they want to order

- Decide together what you will order

Appendix D. Activity Feedback Survey Format Example

\begin{tabular}{|c|c|c|c|c|c|}
\hline & 全〈当てはまらない & 当てはまらない & どちらでもな & 当てはまる & 非常に当てはまる \\
\hline $\begin{array}{l}\text { Marking pauses(は簡単すぎてい) } \\
\text { た。 }\end{array}$ & 0 & 0 & 0 & 0 & 0 \\
\hline $\begin{array}{l}\text { Marking pausesは難しすぎてい } \\
\text { た。 }\end{array}$ & 0 & 0 & 0 & 0 & 0 \\
\hline $\begin{array}{l}\text { Marking pausesは英語練習に役 } \\
\text { に立った。 }\end{array}$ & 0 & 0 & 0 & 0 & 0 \\
\hline
\end{tabular}


(English translation)

Student number:

Please indicate to what extent you agree with the following statements

\begin{tabular}{|c|c|c|c|c|c|}
\hline & $\begin{array}{l}\text { Strongly } \\
\text { disagree }\end{array}$ & Disagree & $\begin{array}{c}\text { Neither } \\
\text { agree or } \\
\text { disagree }\end{array}$ & Agree & $\begin{array}{l}\text { Strongly } \\
\text { agree }\end{array}$ \\
\hline \multicolumn{6}{|l|}{ Marking pauses was too easy } \\
\hline \multicolumn{6}{|l|}{ Marking pauses was too difficult } \\
\hline \multicolumn{6}{|l|}{$\begin{array}{l}\text { Marking pauses was useful for } \\
\text { practising English }\end{array}$} \\
\hline Comment & & & & & \\
\hline
\end{tabular}

